\title{
When Do Nigerian Women of Reproductive Age Initiate and What Factors Influence Their Contraceptive Use? A Contextual Analysis
}

\author{
Michael Ekholuenetale' \\ Samson Olorunju (D) \\ Kayode R Fowobaje (iD) \\ Adeyinka Onikan ${ }^{2}$ \\ Godson Tudeme 3 \\ Amadou Barrow (iD ${ }^{4}$ \\ 'Department of Epidemiology and \\ Medical Statistics, Faculty of Public \\ Health, College of Medicine, University of \\ Ibadan, Ibadan, Nigeria; ${ }^{2}$ Program \\ Management Unit, Management Sciences \\ for Health, Abuja, Nigeria; ${ }^{3}$ School of \\ Medicine, College of Medical Sciences, \\ University of Benin, Benin City, Edo State, \\ Nigeria; ${ }^{4}$ Department of Public \& \\ Environmental Health, School of \\ Medicine \& Allied Health Sciences, \\ University of The Gambia, Kanifing, The \\ Gambia
}

Background: Contraceptive use initiation and continuation is one of the major interventions for reducing maternal deaths worldwide. Nigeria aimed to achieve a $27 \%$ prevalence rate of modern contraceptive uptake by 2020 , however, this seems to have remained unachieved. The objective of this study was to investigate when Nigerian women initiate contraceptive use and its associated factors, using nationally representative data.

Methods: Data on 11,382 Nigerian women (aged 15-49 years) from the 2017 Performance Monitoring and Accountability 2020 (PMA2020) survey were used to determine the prevalence of lifetime contraceptive use. The Kaplan-Meier test was used to determine median time (years) to contraceptive uptake. In addition, the factors associated with contraceptive use were determined using multivariable logistic regression model. Statistical significance was determined at $5 \%$.

Results: The prevalence of modern contraceptive use was $14.2 \%$. There were disparities in the timing (years) of contraceptive use initiation across several women's characteristics. Women from urban residence, highest household wealth index, nulliparous, unmarried, and highly educated women had the minimum median time (years) to contraceptive use initiation. The multivariable logistic model showed that rural women were $26 \%$ less likely to initiate contraceptive use, when compared with the urban dwellers ( $\mathrm{OR}=0.74 ; 95 \% \mathrm{CI}$ : 0.65 , 0.84). Furthermore, married women were $24 \%$ less likely to initiate contraceptive use, when compared with the unmarried $(\mathrm{OR}=0.76 ; 95 \% \mathrm{CI}: 0.63,0.93)$. In addition, geographical region, wealth, television source, ever given birth, education, age, and religion were significantly associated with contraceptive use.

Conclusion: The prevalence of contraceptive use is low in Nigeria. There were differences in contraceptive use initiation among women of reproductive age in Nigeria. There is a need to adopt sustainable strategies to improve contraceptive uptake and to re-iterate the benefits of contraception, including providing enlightenment programs among key populations such as the rural dwellers and low income earners.

Keywords: inequality, family planning, PMA2020, FP2020, Nigeria, contraceptive use

\section{Introduction}

Despite a decline of $34 \%$ in maternal deaths reported in 1990, developing countries account for 99\%; with sub-Saharan Africa (SSA) and South Asia jointly accounting for $87 \%$ of the global deaths of these women due to pregnancy-related complications. $^{1-3}$ Even though about 222 million women of reproductive age desire to delay or stop childbearing, they are not using any contraceptive method, which is among other forms of reducing pregnancy-related complications responsible for the high maternal death rates in developing countries. ${ }^{4}$
Correspondence: Amadou Barrow Email abarrow@utg.edu.gm 
To achieve the three-quarters reduction goal in maternal mortality rate, Family Planning 2020 (FP2020) launched a crucial campaign that supports the rights of an additional 120 million women of reproductive age to freely decide for themselves whether, when, and how many children they want to have by using modern contraceptives, ${ }^{5}$ which is also aimed at meeting both Goal 3 and 5 of the Sustainable Development Goals (SDGs) which relate to good health and wellbeing and gender equality respectively. ${ }^{5,6}$ Increased access to modern contraceptive and its effective utilization have shown to be cost-effective and a key intervention for reducing maternal and neonatal deaths. ${ }^{7-13}$ Specifically, an estimated $29 \%$ reduction in maternal deaths globally has been associated with family planning and its use prevented about 272,000 maternal deaths in $2010 .^{8}$

However, Nigeria remains one of the leading countries with high maternal deaths globally and indeed in SSA. ${ }^{6,13-}$ ${ }^{15}$ Even though there had been a reported decline of $52 \%$ in Maternal Mortality Ratio (MMR) within 13 years (19902013), many women still die due to pregnancy-related causes with estimates of MMR suggesting no substantial difference. ${ }^{8,13}$ Despite successful program implementation, the utilization of any method of delaying or preventing unwanted pregnancy is still low, ${ }^{16-19}$ with an estimated growth rate of $3.2 \%$ per year and a high fertility rate of 5.5 children per woman. ${ }^{18,20}$ Also, fertility desire continues to be on the increase among both men and women. ${ }^{19,21}$ This poor level of utilization has been linked to insufficient funding of the family planning programs, educational level and socioeconomic status of the couple. ${ }^{12,13,18}$ Studies have shown that unexpected or unplanned pregnancies, unsafe abortion, neonatal death, and maternal mortality due to pregnancy-related complications are linked with low contraceptive utilization. ${ }^{19,22}$ The use of modern contraceptives translates to the prevention of unexpected or unplanned pregnancies and unsafe abortions, thereby reducing the burden of maternal mortality. ${ }^{15}$

There are regional differences in the reported prevalence of contraceptive use in Nigeria; with the Northern region having the lowest contraceptive prevalence, despite the country having the second highest maternal mortality burden globally. ${ }^{4,13,15,20,23,24}$ Variations in contraceptive use with respect to socioeconomic status, religion, location, and educational level also exist in the literature. $^{4,12,13,16,19,20,23,25,26}$ There is a need to understand the time to contraceptive use uptake and investigate the associated factors. Currently, there is little or dearth of information on timing of contraceptive use initiation, and this information will be useful for effective family planning program and also to improve the level of contraceptive use in Nigeria which will in turn help the nation derive the required benefits from family planning programs and ultimately reduce the high level of maternal mortality. Therefore, this study was conducted to examine when Nigerian women initiate contraceptive use and its associated factors, using a large dataset.

\section{Methodology} Data Source

We conducted secondary data analysis using publicly available Performance Monitoring and Accountability 2020 (PMA2020) data in Nigeria with nationally representative samples. The data were collected in 2017. PMA2020 used female resident enumerators to conduct surveys among 10,070 households and 11,106 consenting women aged 15 to 49 years. The sampling procedure was based on a multi-stage sampling approach in seven regionally representative states. Clusters of Enumeration Areas (302) from a national master sampling frame were extracted for this survey. The PMA2020 project was implemented by local partner universities and research organizations with technical support and direction provided by the Bill and Melinda Gates Institute for Population and Reproductive Health in the Department of Population, Family and Reproductive Health at the Johns Hopkins Bloomberg School of Public Health. The major focus of PMA2020 data is the utilization of contraceptive methods by women of reproductive age, childhood nutrition, and unintended pregnancies. ${ }^{27}$ The details of how the women were identified from the households and how data was collected have been reported elsewhere. ${ }^{5,28-31}$

\section{Measurement of Variables}

The outcome variables included: time (in years) to uptake of contraceptive method, age (in years) at contraceptive initiation, age (in years) at sexual debut and contraceptive use (yes versus no). The explanatory factors included: age (in years), geographical zone, place of residence, religion, heard about family planning on radio, heard about family planning on television, read about family planning in newspaper/magazine, number of children ever born, ever given birth, marital status, highest level of school attended, not using contraceptive to limit or space childbirth, wealth index, as shown in Table 1. 
Table I Variables' Selection and Measurement

\begin{tabular}{|c|c|c|}
\hline Variable & Categories & Description \\
\hline \multicolumn{3}{|l|}{ Outcome variables } \\
\hline $\begin{array}{l}\text { Time (years) to uptake of } \\
\text { contraceptive }\end{array}$ & & $\begin{array}{l}\text { This was calculated for respondents using the time difference between } \\
\text { the year of first contraceptive use and age at first sexual intercourse. Non- } \\
\text { users of contraceptives were censored and women who were yet to have } \\
\text { sexual intercourse were removed. }\end{array}$ \\
\hline $\begin{array}{l}\text { Age at contraceptive } \\
\text { initiation }\end{array}$ & & $\begin{array}{l}\text { This is the age of the woman when she initiated the use of contraceptive } \\
\text { method to prevent getting pregnant. }\end{array}$ \\
\hline Age at sexual debut & & This is the age of the respondent at her first sexual intercourse. \\
\hline Contraceptive use & $\begin{array}{l}\text { Ever used anything to delay or avoid } \\
\text { getting pregnant } \\
\text { Currently use any contraceptive method } \\
\text { Currently use modern contraceptive } \\
\text { Currently use traditional contraceptive } \\
\text { method }\end{array}$ & $\begin{array}{l}\text { These categories were measured dichotomously (Yes/No) to determine the } \\
\text { level of contraceptive utilization among women of reproductive age. }\end{array}$ \\
\hline \multicolumn{3}{|l|}{ Explanatory variables } \\
\hline Age (years) & $\begin{array}{l}15-19 / 20-24 / 25-29 / 30-34 / 35-39 / 40- \\
44 / 45-49\end{array}$ & The current age of respondents were re-grouped in 5 year intervals. \\
\hline Zone & $\begin{array}{l}\text { North Central/North East/North West/ } \\
\text { South East/South South/South West }\end{array}$ & $\begin{array}{l}\text { This is the geopolitical zones of origin of respondents. Nigeria has six } \\
\text { geopolitical zones }\end{array}$ \\
\hline Place of residence & Urban/Rural & Respondents were grouped by place of residence. \\
\hline Religion & $\begin{array}{l}\text { Catholic/Other Christian/lslam/ } \\
\text { Traditionalist/Other religion }\end{array}$ & $\begin{array}{l}\text { The religious affiliations of respondents were categorized as prevalent in } \\
\text { Nigeria. }\end{array}$ \\
\hline $\begin{array}{l}\text { Heard about family } \\
\text { planning on radio }\end{array}$ & Yes/No & \multirow[t]{3}{*}{$\begin{array}{l}\text { The prominent media of family planning information were measured } \\
\text { dichotomously }\end{array}$} \\
\hline $\begin{array}{l}\text { Heard about family } \\
\text { planning on television }\end{array}$ & Yes/No & \\
\hline $\begin{array}{l}\text { Read about family } \\
\text { planning in newspaper/ } \\
\text { magazine }\end{array}$ & Yes/No & \\
\hline $\begin{array}{l}\text { Number of children ever } \\
\text { born }\end{array}$ & $\mathrm{Nil} / \mathrm{I}-2 / 3-4 />4$ & $\begin{array}{l}\text { Total number of children ever born was used to measure fertility rate of } \\
\text { respondents. }\end{array}$ \\
\hline Ever given birth & Nulliparous/Parous & $\begin{array}{l}\text { The parity of respondents was measured dichotomously on whether } \\
\text { a woman had ever given birth or not. }\end{array}$ \\
\hline Marital status & Never married/married & This variable describes the type of relationship of each respondent. \\
\hline $\begin{array}{l}\text { Highest level of school } \\
\text { attended }\end{array}$ & $\begin{array}{l}\text { No formal education/Primary/ } \\
\text { Secondary/Higher }\end{array}$ & Educational attainment was determined by the level completed \\
\hline $\begin{array}{l}\text { Not using contraceptive } \\
\text { to limit or space } \\
\text { childbirths }\end{array}$ & & $\begin{array}{l}\text { The variable: not using contraceptive to limit or space childbirths measured } \\
\text { in binary form }\end{array}$ \\
\hline
\end{tabular}


Table I (Continued).

\begin{tabular}{|l|l|l|}
\hline Variable & Categories & Description \\
\hline Wealth index & $\begin{array}{l}\text { Lowest (Poorest)/Lower (Poorer)/ } \\
\text { Middle/Higher (Richer)/Highest } \\
\text { (Richest) }\end{array}$ & $\begin{array}{l}\text { PMA2020 include questions about household assets including type of floor, } \\
\text { roof, walls; source of water including open well, stream, or piped system; } \\
\text { other assets including radio, fan, automobile, electricity, television, } \\
\text { refrigerator, cooking fuel, furniture. Using these indicators, economic status } \\
\text { was measured by computing a "wealth index" using principal component } \\
\text { analysis. The factor loadings and z-scores were calculated. For each } \\
\text { household, the indicator values were multiplied by the loadings and summed } \\
\text { to produce the household's wealth index value. The standardized z-score } \\
\text { was used to disentangle the overall assigned scores to quintiles. }\end{array}$ \\
\hline
\end{tabular}

\section{Ethical Approval}

Ethical approval was sought from the Nigeria National Health Research ethics committee by the data originators and granted before starting the survey. Also, informed consent was received from the participants before interviewing them. We obtained the approval from PMA2020 Centre for Research, Evaluation Resources and Development (CRERD), Bayero University Kano (BUK), and the Johns Hopkins Bloomberg School of Public Health (JHSPH) to use the data. CRERD implemented PMA2020 in Nigeria.

\section{Data Analysis}

PMA2020 used complex sampling design that involved clustering of households. Hence, we applied sampling weights to account for differentials in probabilities of selection. The collinearity testing method utilized the variance inflation factor of 10 to detect interdependence between variables. A cut-off of 10 and above was used to examine the multicollinearity, known to cause major concerns. The variables; ever given birth and total number of children ever born had interdependence. Therefore, the variable "ever given birth" was retained in the logistic regression model. ${ }^{32}$ We computed the prevalence of lifetime contraceptive use to provide the context in which birth dynamics are occurring and across all variables to examine the statistical significance of cross-tabulation results. The median time (years) to contraceptive uptake was used to determine timing of contraceptive initiation using the Kaplan-Meier survival analysis. ${ }^{33}$ We conducted multivariable logistic regression to determine the factors associated with contraceptive use. Analyses were conducted using Stata Version 14 (StataCorp 2014). Statistical significance was determined using $5 \%$.

\section{Results}

Results from Table 2 show the distribution of contraceptive use by women's characteristics. About 49.8\%, $45.3 \%$, and $32.3 \%$ of women from South West, South South and South East reported contraceptive use respectively. Urban women or those from households with higher wealth index had higher proportion of contraceptive use. The median (minimum, maximum) time (years) to contraceptive uptake was also estimated. Details of the distribution of other variables are presented in Table 2. The Chi-squared bivariate analysis showed that all variables were significantly associated with contraceptive use.

\section{Time (In Years) Between Age at First Sexual Intercourse and Age at Contraceptive Use Initiation}

The Kaplan Meier plots showed disparities between age at first sexual intercourse and age at contraceptive use initiation. South-South and South-West zones had the least median time (years) to contraceptive use initiation. Women from urban residence, highest household wealth index, those who had not given birth, unmarried, with higher educational attainment and those of young age (15-19 years) had the minimum median time (years) to contraceptive use initiation. Women who were using contraceptives to limit or space childbirths or with other religions besides Christianity, Islam, and Tradition had the minimum median time (years) to family planning initiation. Furthermore, women who heard about family planning through television or read about family planning in newspaper/magazine had minimum median time (years) to family planning initiation. See the details in Figures 1-13. 
Table 2 Distribution of Women's Characteristics

\begin{tabular}{|c|c|c|c|c|}
\hline \multirow[t]{2}{*}{ Variable } & \multirow[t]{2}{*}{ n (\%) } & \multicolumn{2}{|c|}{$\begin{array}{l}\text { Done Anything } \\
\text { to Delay or } \\
\text { Avoid Getting } \\
\text { Pregnant }\end{array}$} & \multirow[t]{2}{*}{ P-value } \\
\hline & & Yes (\%) & No (\%) & \\
\hline $\begin{array}{l}\text { Geopolitical zone } \\
\text { North Central } \\
\text { North East } \\
\text { North West } \\
\text { South East } \\
\text { South South } \\
\text { South West }\end{array}$ & $\begin{array}{l}1853(16.3) \\
822(7.2) \\
4593(40.4) \\
1407(12.4) \\
1167(10.3) \\
1540(13.5)\end{array}$ & $\begin{array}{l}28.6 \\
21.1 \\
21.0 \\
32.3 \\
45.3 \\
49.8\end{array}$ & $\begin{array}{l}71.4 \\
78.9 \\
79.0 \\
67.7 \\
54.7 \\
50.2\end{array}$ & $<0.00 I^{*}$ \\
\hline $\begin{array}{l}\text { Place of residence } \\
\text { Urban } \\
\text { Rural }\end{array}$ & $\begin{array}{l}5334(46.9) \\
6048(53.1)\end{array}$ & $\begin{array}{l}38.2 \\
22.8\end{array}$ & $\begin{array}{l}61.8 \\
77.2\end{array}$ & $<0.001 *$ \\
\hline $\begin{array}{l}\text { Wealth index } \\
\text { Lowest } \\
\text { Lower } \\
\text { Middle } \\
\text { Higher } \\
\text { Highest }\end{array}$ & $\begin{array}{l}3362(29.6) \\
2666(23.4) \\
1955(17.2) \\
1752(15.4) \\
164 \mid(14.4)\end{array}$ & $\begin{array}{l}16.5 \\
28.5 \\
33.8 \\
40.8 \\
44.2\end{array}$ & $\begin{array}{l}83.5 \\
71.5 \\
66.2 \\
59.3 \\
55.8\end{array}$ & $<0.001 *$ \\
\hline $\begin{array}{l}\text { Heard about family } \\
\text { planning on radio } \\
\text { Yes } \\
\text { No }\end{array}$ & $\begin{array}{l}6893(60.7) \\
447 \mid(39.3)\end{array}$ & $\begin{array}{l}34.0 \\
23.9\end{array}$ & $\begin{array}{l}66.0 \\
76.1\end{array}$ & $<0.001 *$ \\
\hline $\begin{array}{l}\text { Heard about family } \\
\text { planning on } \\
\text { television } \\
\text { Yes } \\
\text { No }\end{array}$ & $\begin{array}{l}4346(38.3) \\
7017(61.7)\end{array}$ & $\begin{array}{l}42.5 \\
22.3\end{array}$ & $\begin{array}{l}57.5 \\
77.7\end{array}$ & $<0.001 *$ \\
\hline $\begin{array}{l}\text { Read about family } \\
\text { planning in } \\
\text { newspaper/magazine } \\
\text { Yes } \\
\text { No }\end{array}$ & $\begin{array}{l}2070(\mid 8.2) \\
9277(8 \mid .8)\end{array}$ & $\begin{array}{l}43.8 \\
27.0\end{array}$ & $\begin{array}{l}56.2 \\
73.0\end{array}$ & $<0.001 *$ \\
\hline $\begin{array}{l}\text { Number of children } \\
\text { ever born } \\
\text { Nil } \\
\text { I-2 } \\
3-4 \\
>4\end{array}$ & $\begin{array}{l}3643(32.0) \\
259 \mid(22.8) \\
2276(20.0) \\
2859(25.2)\end{array}$ & $\begin{array}{l}15.3 \\
31.1 \\
42.9 \\
37.6\end{array}$ & $\begin{array}{l}84.7 \\
68.9 \\
57.1 \\
62.4\end{array}$ & $<0.001 *$ \\
\hline $\begin{array}{l}\text { Ever given birth } \\
\text { Yes } \\
\text { No }\end{array}$ & $\begin{array}{l}7730(68.0) \\
3646(32.0)\end{array}$ & $\begin{array}{l}37.0 \\
15.2\end{array}$ & $\begin{array}{l}63.0 \\
84.8\end{array}$ & $<0.00 I^{*}$ \\
\hline $\begin{array}{l}\text { Marital status } \\
\text { Never married } \\
\text { Married }\end{array}$ & $\begin{array}{l}3194(28.1) \\
8184(71.9)\end{array}$ & $\begin{array}{l}18.5 \\
34.5\end{array}$ & $\begin{array}{l}81.5 \\
65.5\end{array}$ & $<0.001 *$ \\
\hline
\end{tabular}

(Continued)
Table 2 (Continued).

\begin{tabular}{|c|c|c|c|c|}
\hline \multirow[t]{2}{*}{ Variable } & \multirow[t]{2}{*}{ n (\%) } & \multicolumn{2}{|c|}{$\begin{array}{l}\text { Done Anything } \\
\text { to Delay or } \\
\text { Avoid Getting } \\
\text { Pregnant }\end{array}$} & \multirow[t]{2}{*}{ P-value } \\
\hline & & Yes (\%) & No (\%) & \\
\hline $\begin{array}{l}\text { Highest level of } \\
\text { school attended } \\
\text { No formal } \\
\text { education } \\
\text { Primary } \\
\text { Secondary } \\
\text { Higher }\end{array}$ & $\begin{array}{l}2590(22.8) \\
2135(18.8) \\
4957(43.6) \\
1697(14.9)\end{array}$ & $\begin{array}{l}15.1 \\
29.1 \\
32.3 \\
47.3\end{array}$ & $\begin{array}{l}84.9 \\
70.9 \\
67.7 \\
52.7\end{array}$ & $<0.00 I^{*}$ \\
\hline $\begin{array}{l}\text { Age (years) of } \\
\text { respondent } \\
15-19 \\
20.24 \\
25-29 \\
30-34 \\
35-39 \\
40-44 \\
45-49\end{array}$ & $\begin{array}{l}2417(21.2) \\
2000(17.6) \\
1995(17.5) \\
1833(16.1) \\
1409(12.4) \\
967(8.5) \\
761(6.7)\end{array}$ & $\begin{array}{l}7.0 \\
24.3 \\
36.4 \\
40.8 \\
44.4 \\
41.0 \\
7.8\end{array}$ & $\begin{array}{l}93.0 \\
75.7 \\
63.6 \\
59.2 \\
55.6 \\
59.0 \\
6.2\end{array}$ & $<0.00 I^{*}$ \\
\hline $\begin{array}{l}\text { Religion } \\
\text { Catholic } \\
\text { Other Christian } \\
\text { Islam } \\
\text { Traditionalist } \\
\text { Other religion }\end{array}$ & $\begin{array}{l}1566(13.8) \\
4108(36.2) \\
5449(47.9) \\
110(1.0) \\
122(1.1)\end{array}$ & $\begin{array}{l}35.1 \\
41.4 \\
19.9 \\
22.7 \\
39.3\end{array}$ & $\begin{array}{l}64.9 \\
58.6 \\
80.1 \\
77.3 \\
60.7\end{array}$ & $<0.001 *$ \\
\hline $\begin{array}{l}\text { Not limiting or } \\
\text { spacing childbirths } \\
\text { No } \\
\text { Yes }\end{array}$ & $\begin{array}{l}9127(80.3) \\
2242(19.7)\end{array}$ & $\begin{array}{l}32.1 \\
21.7\end{array}$ & $\begin{array}{l}67.9 \\
78.3\end{array}$ & $<0.001 *$ \\
\hline
\end{tabular}

Notes: $P$ obtained using Chi-squared test; *significant at $p<0.05$.

The results showed that women from North-East, NorthWest and South-East were less likely to initiate contraceptive methods, when compared with women from North-Central after adjusting for other covariates. The rural women were $26 \%$ less likely to take up contraceptive method, when compared with the urban dwellers $(\mathrm{OR}=$ 0.74; 95\% CI: $0.65,0.84)$. Women with higher household wealth index were more likely to take up contraceptive method, when compared with women from poorest household after adjusting for other covariates. In addition, women who heard about family planning through television were 1.34 times more likely to use contraceptive method, when compared with women who did not hear about 


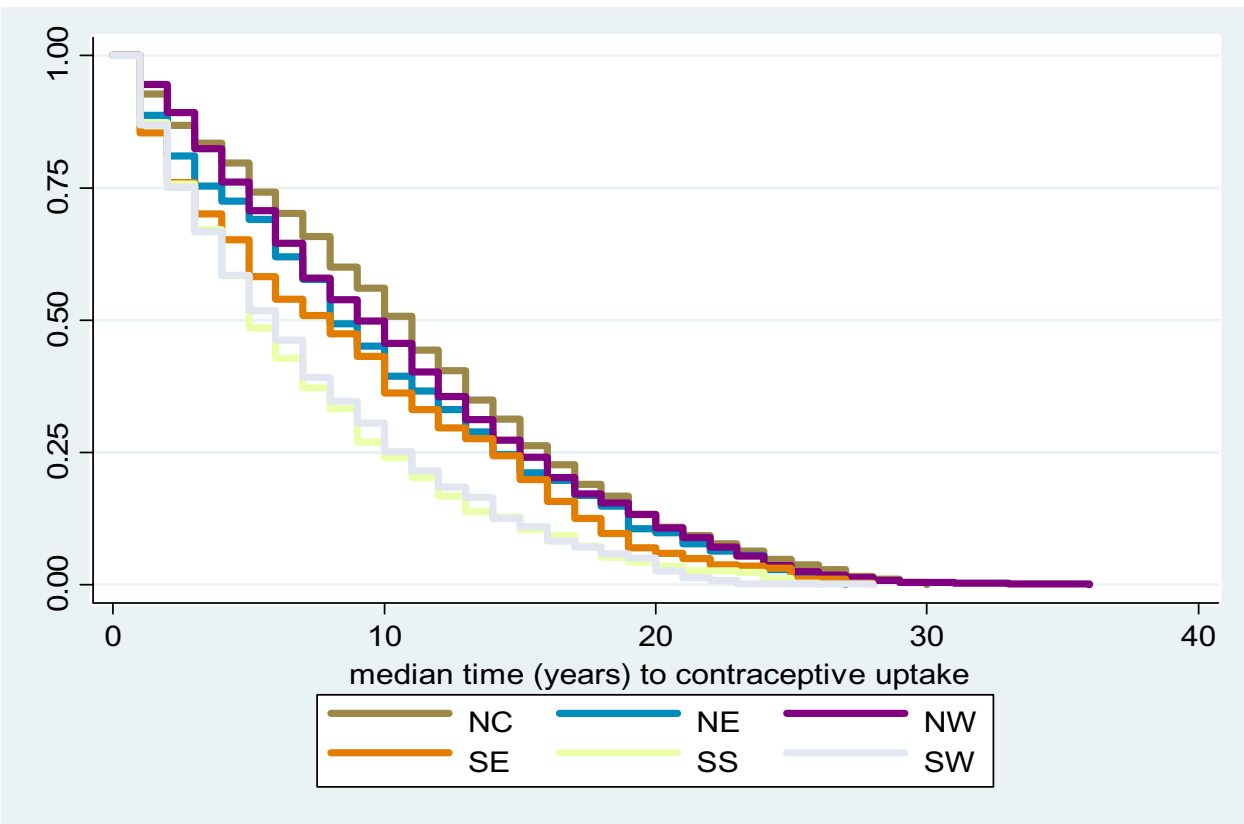

Figure I Median years to FP initiation by geopolitical zone.

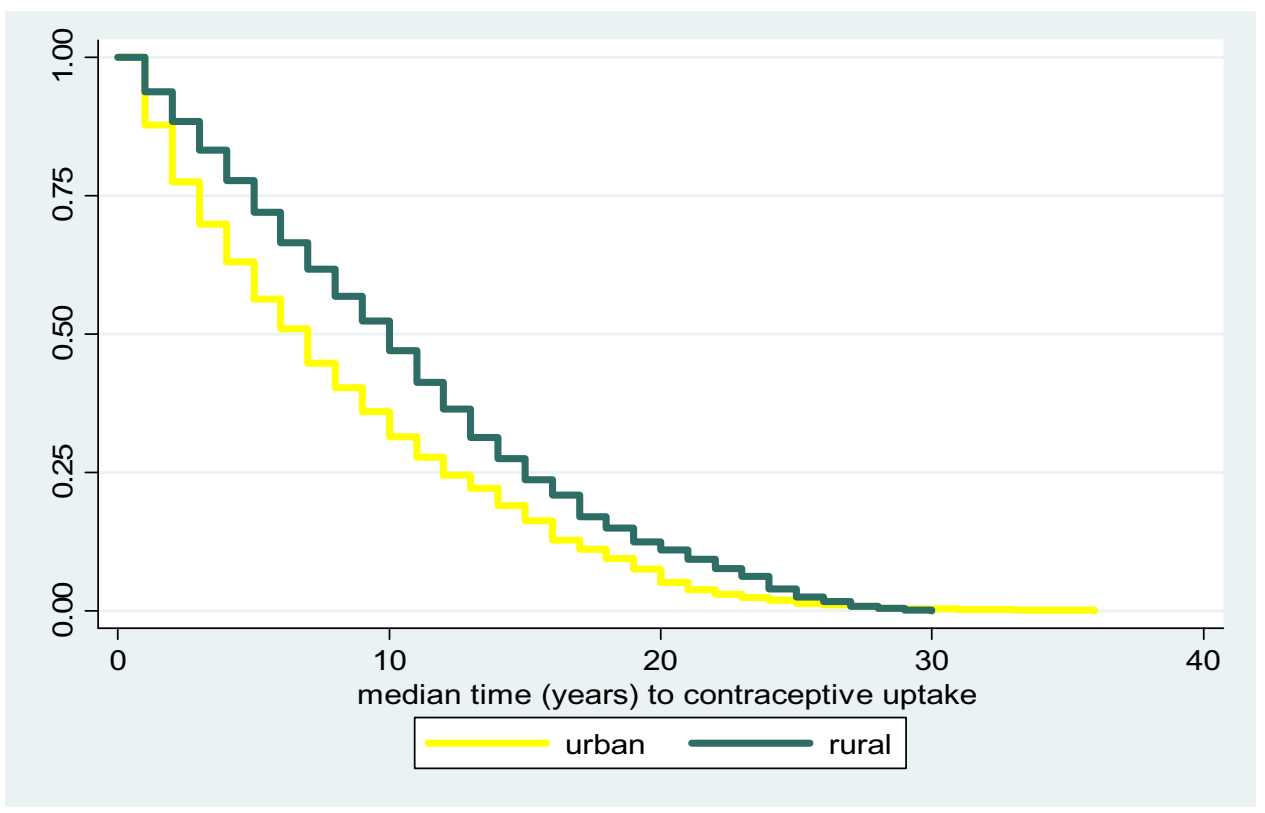

Figure 2 Median years to FP initiation by place of residence.

contraception through television $(\mathrm{OR}=1.34 ; 95 \% \mathrm{CI}: 1.19$, 1.51). Women who had ever given birth were 3.73 times more likely to use contraceptive method, when compared with women who had not given birth $(\mathrm{OR}=3.73 ; 95 \% \mathrm{CI}$ : $3.08,4.51)$. Furthermore, married women were $24 \%$ less likely to take up contraceptive method, when compared with unmarried women after adjusting for other covariates
$(\mathrm{OR}=0.76$; 95\% CI: 0.63, 0.93). Women with formal education or higher age level were more likely to take up contraceptive method, when compared with women with no formal education or aged 15-19 years, after adjusting for other covariates. Based on religious background, women of Islamic belief were $52 \%$ less likely to take up contraceptive method, when compared with Catholic women after 


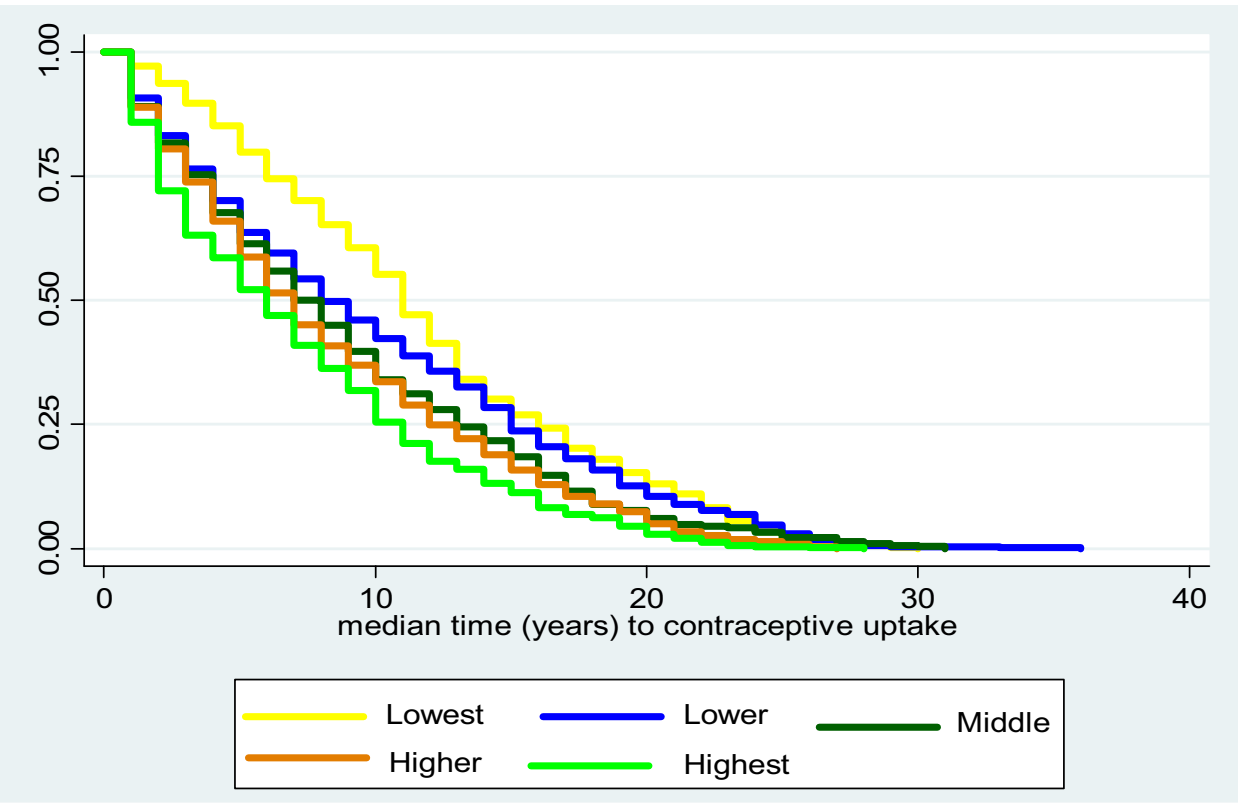

Figure 3 Median years to FP initiation by wealth index.

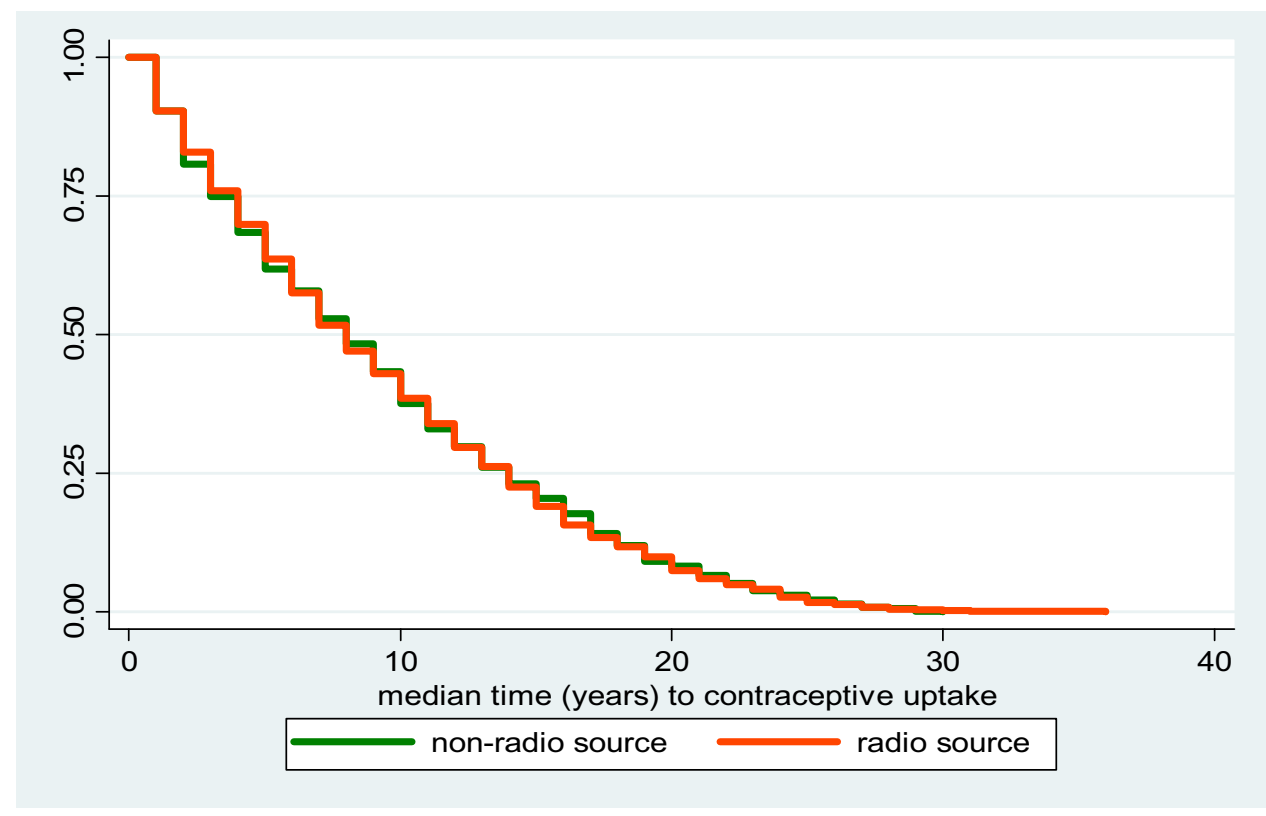

Figure 4 Median years to FP initiation and awareness through radio.

adjusting for other covariates. Women who did not limit or space childbirths were $55 \%$ less likely to take up any contraceptive, when compared with women who did limit or space childbirths $(\mathrm{OR}=0.45 ; 95 \% \mathrm{CI}$ : $0.40,0.51)$. See details in Table 3.

\section{Discussion}

In this study, we looked at the prevalence, timing (years), and the factors associated with contraceptive use among women of reproductive age in Nigeria using the PMA2020 survey data. Overall, there was low prevalence of contraceptive use. Similar to the findings of previous studies, ${ }^{34}$ a higher proportion of urban residents had contraceptive use, than the rural residents. Also, contraceptive use was highest among respondents with the highest household wealth quintile, those that have heard about it on TV and radio program, or read about it in newspaper/magazine. Other studies have suggested a higher household wealth 


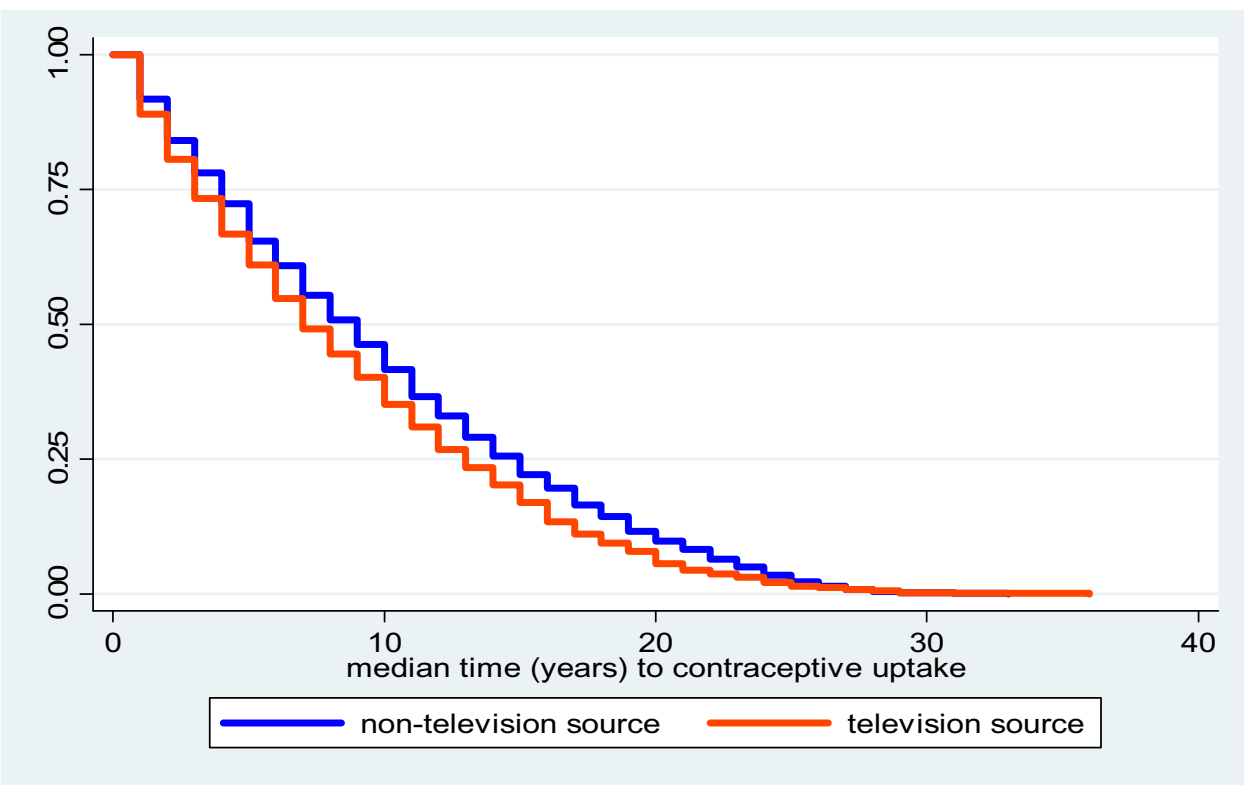

Figure 5 Median years to FP initiation and awareness through TV channel.

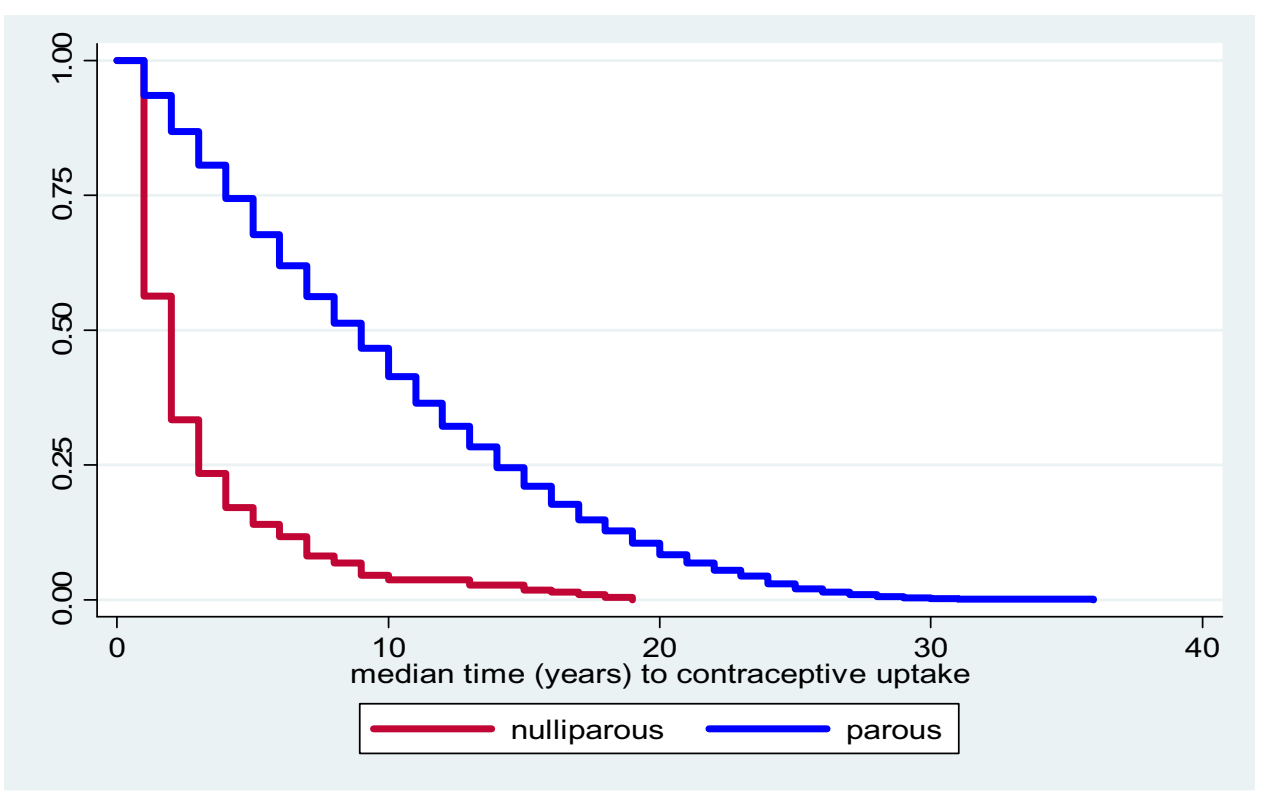

Figure 6 Median years to FP initiation by parity (ever given birth).

quintile as strong indicator for uptake of a modern contraceptive method. ${ }^{8,24,34}$ The total fertility rate for Nigeria is 5.5 and interestingly, uptake is highest among those with 3-4 children. ${ }^{18,20}$ This suggests that most women see the birth of a third or fourth child as an indication to stop child-bearing. Expectedly, the proportion of women using contraception increased with increasing educational level and age. Couples' socio-economic status and educational level have been linked by previous studies to poor level of contraceptive utilization. ${ }^{12,13,18}$

Similar to other studies, regional differences in the reported prevalence of contraceptive utilization in Nigeria exit. ${ }^{4,13,15,20,23,34}$ For instance, the north central region of Nigeria with the highest prevalence of contraceptive usage, in the North, still lags behind the south East region with the lowest prevalence rate in the south. 


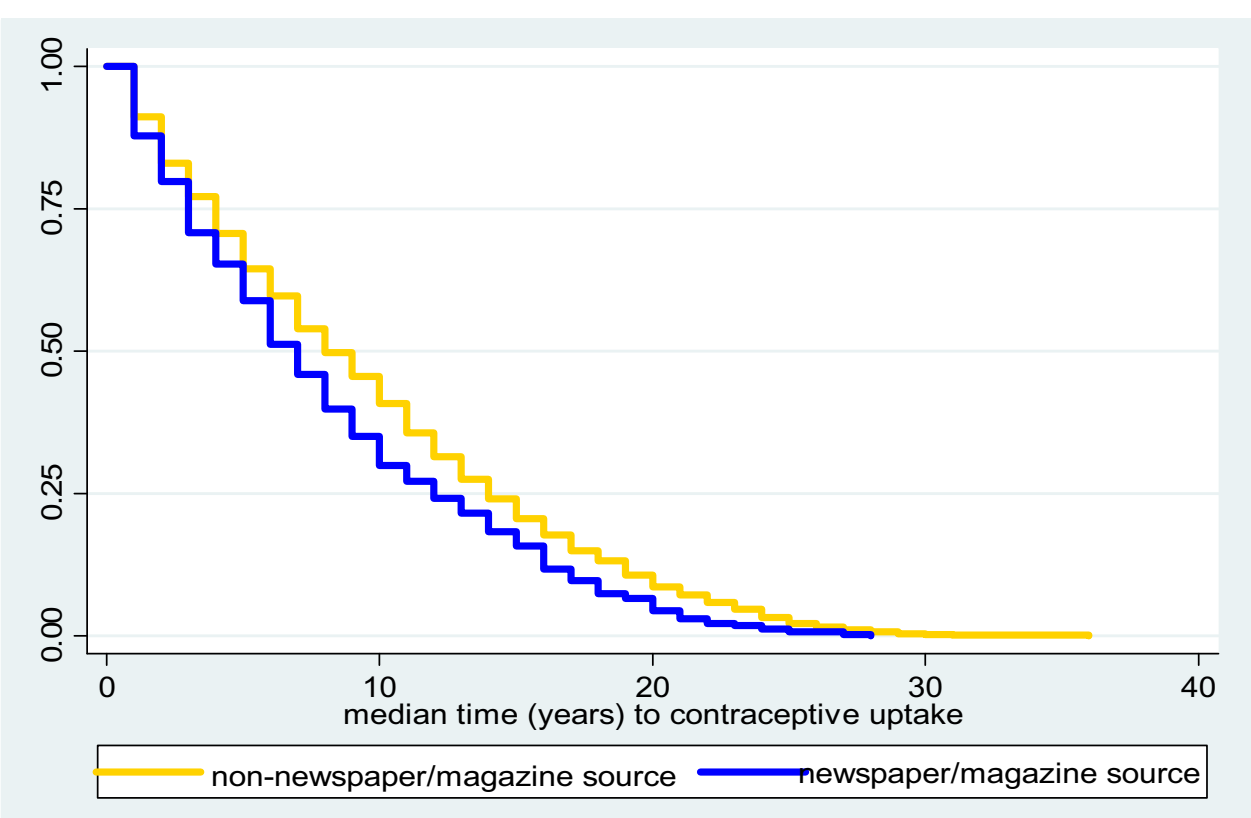

Figure 7 Median years to FP initiation and awareness through newspaper/magazine.

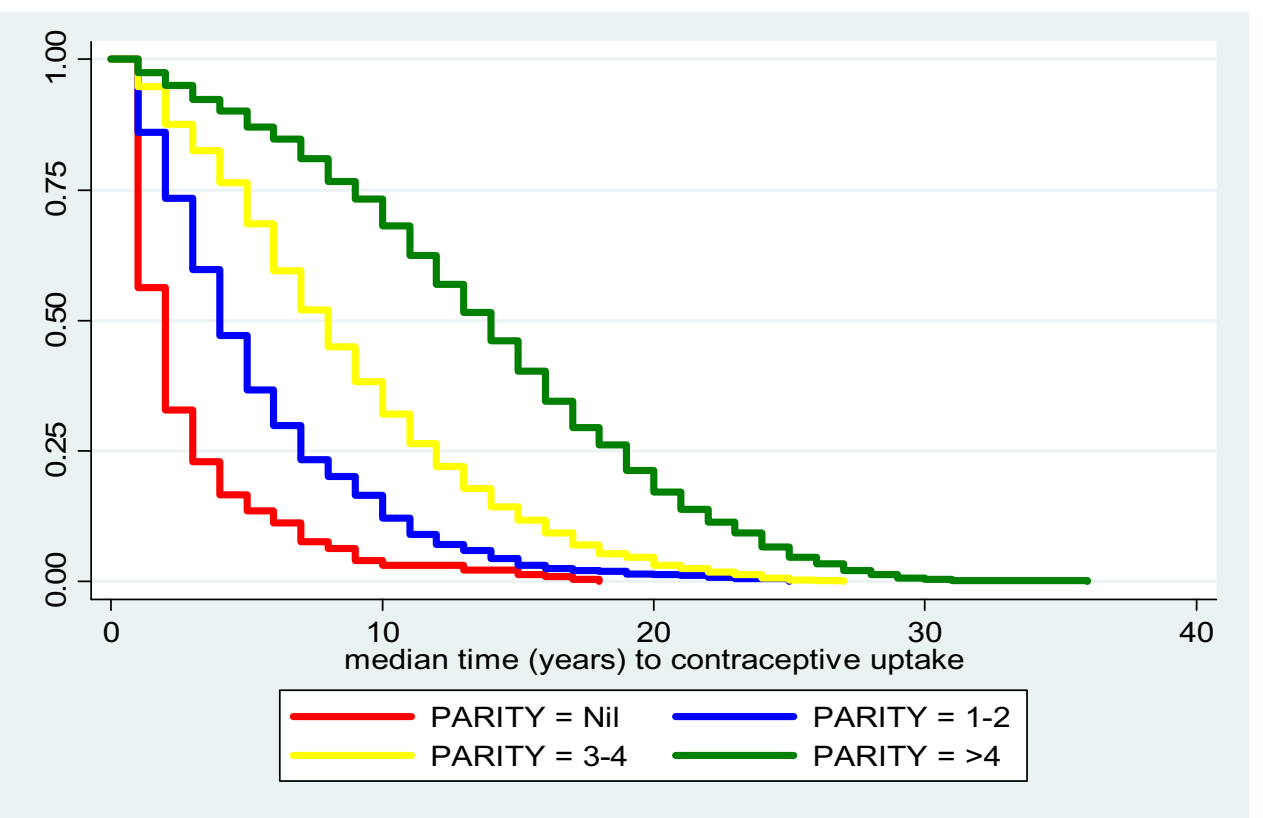

Figure 8 Median years to FP initiation by number of children ever born.

Interestingly, despite having the second highest maternal mortality burden globally, the Northern region of the country has the lowest prevalence of contraceptive utilization. ${ }^{4,13,15,20,23,34}$ A look at the prevalence of contraceptive use based on religion may give a better understanding of these regional differences. The north, which is predominantly Islam, has the lowest prevalence rate (one-fifth), against (one-third) which is recorded for the catholic faith (predominantly resident in the south east) and $41.4 \%$ recorded for other Christians (predominantly South westerners). This suggests that there may be some religious practices supporting or discouraging contraceptive use. This view is supported by studies using a nationally representative sample. ${ }^{10}$ 


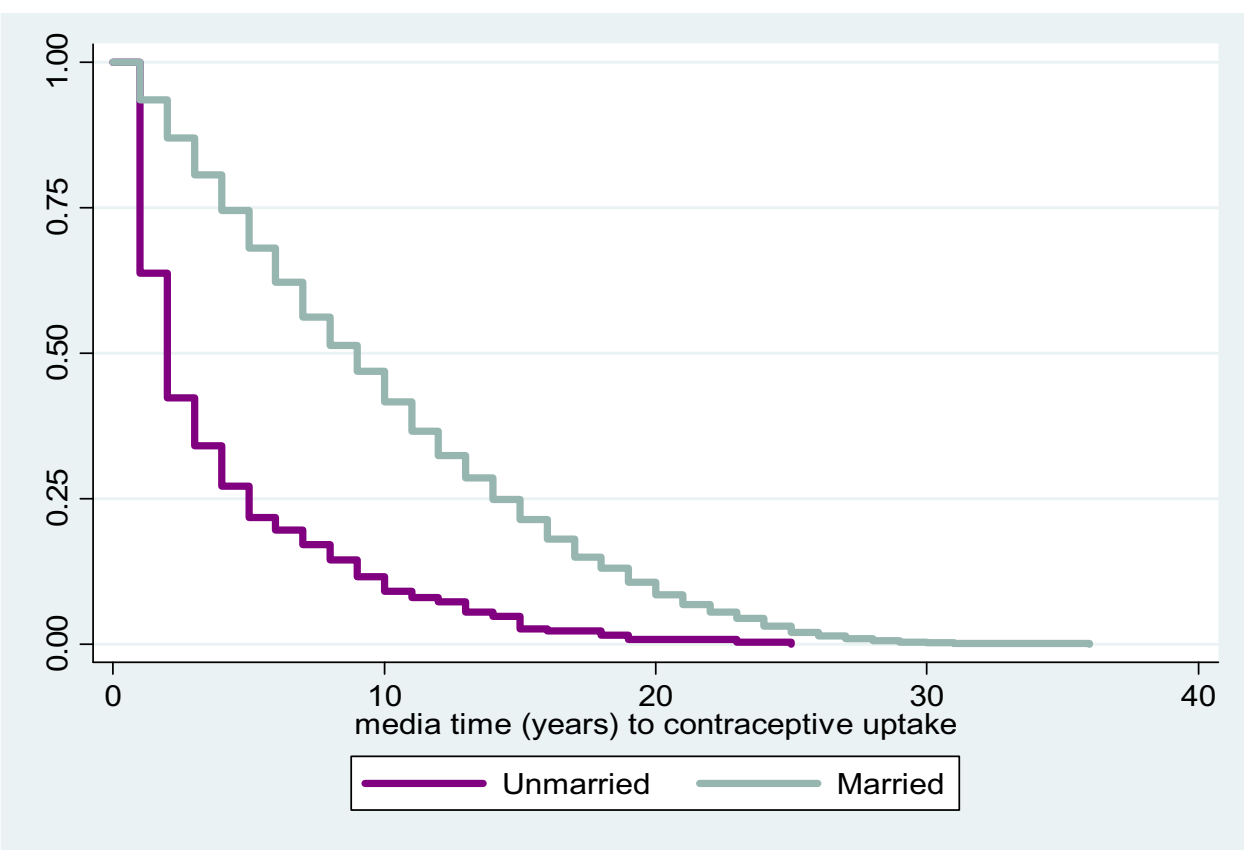

Figure 9 Median years to FP initiation by marital status.

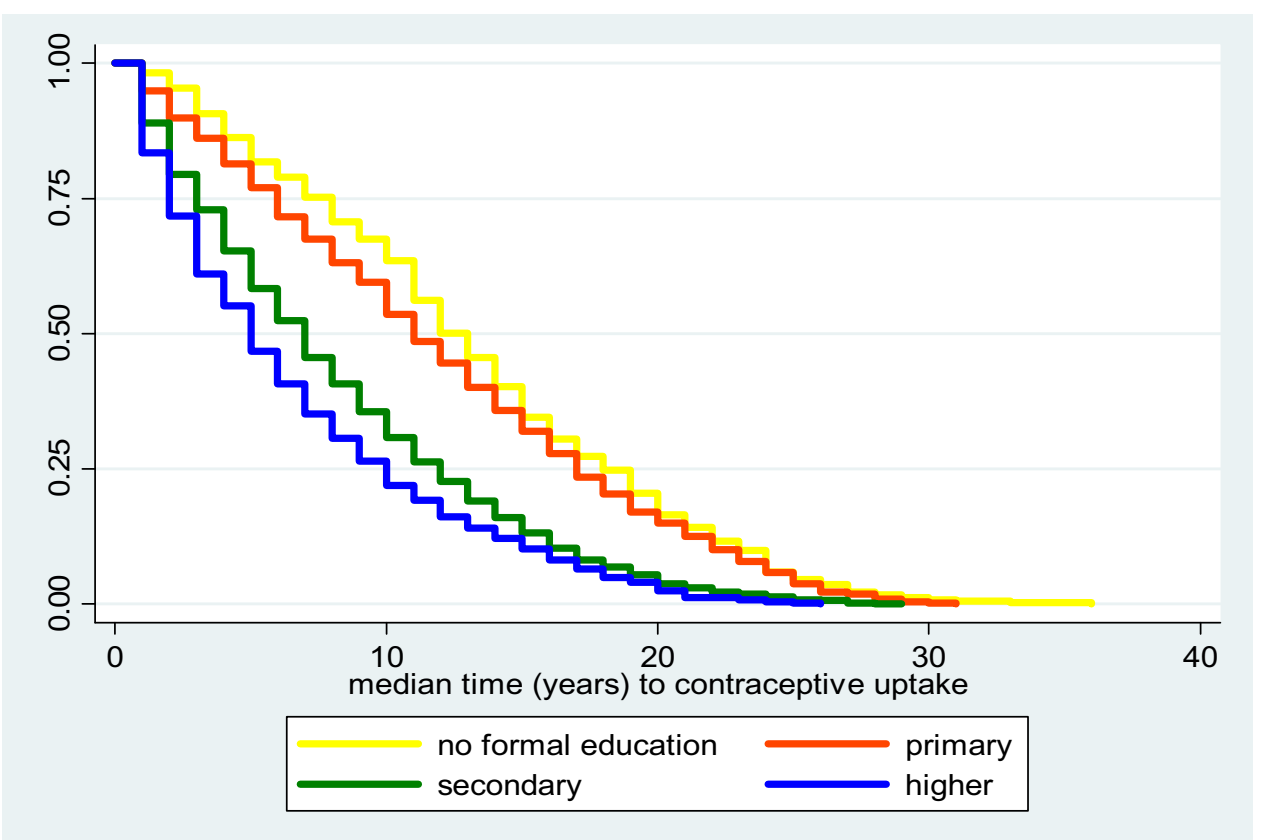

Figure 10 Median years to FP initiation by educational level.

There were clear regional, locality, wealth quintile, parity, marital status, age, and educational differences in the timing of uptake of contraception among Nigerian women. The southern regions had earlier median times than Northern regions. Previous studies have suggested that contraceptive use is more pronounced in the southern region of the country., $43,15,20,23,34$ Similarly, women in the higher wealth index and with higher educational level had earlier uptake time of contraceptives than those in the lower wealth quintile and educational level respectively. This suggests that educational exposure and high social class are good 


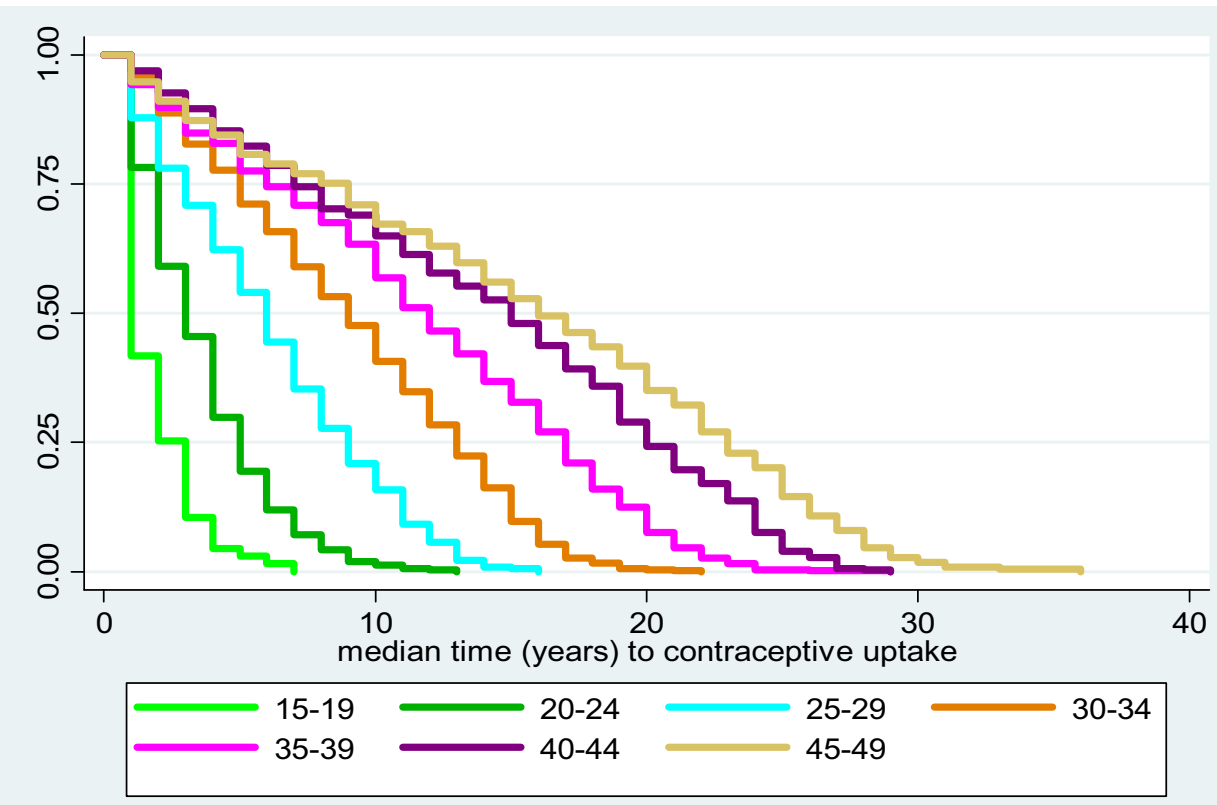

Figure II Median years to FP initiation by age (years).

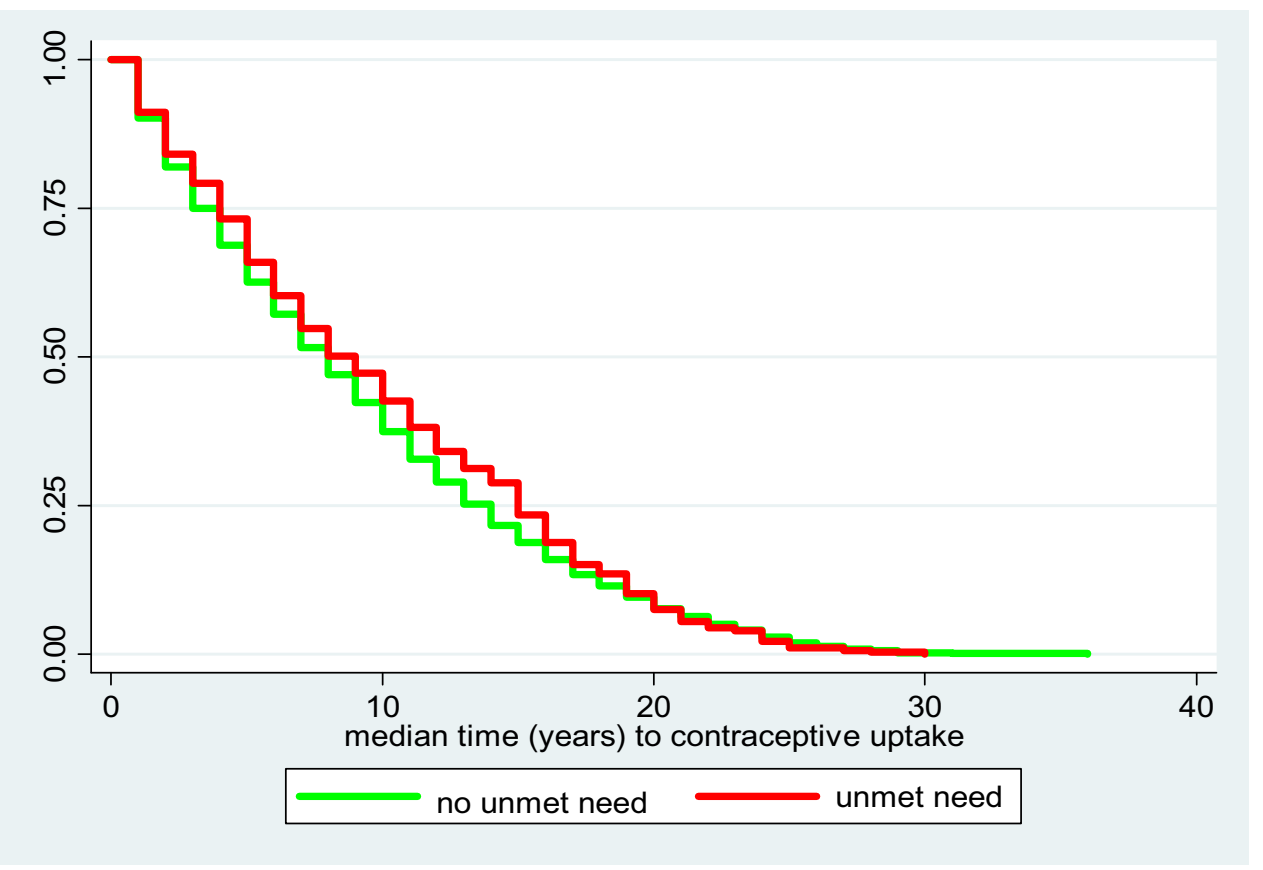

Figure 12 Median years to FP initiation by unmet need.

incentives for the uptake of contraceptive use. Urban residents, women with access to newspaper and television had a lower median time to use of contraceptives than rural residents, women with no access to newspaper/magazine and television source respectively. This may not be unconnected to the ease of access to these information sources (television, newspaper/magazine) by urban residents in comparison with rural residents. Nulliparous women and unmarried women had lower median time to contraceptive use than parous women and married women. $4,13,15,20,23$ 


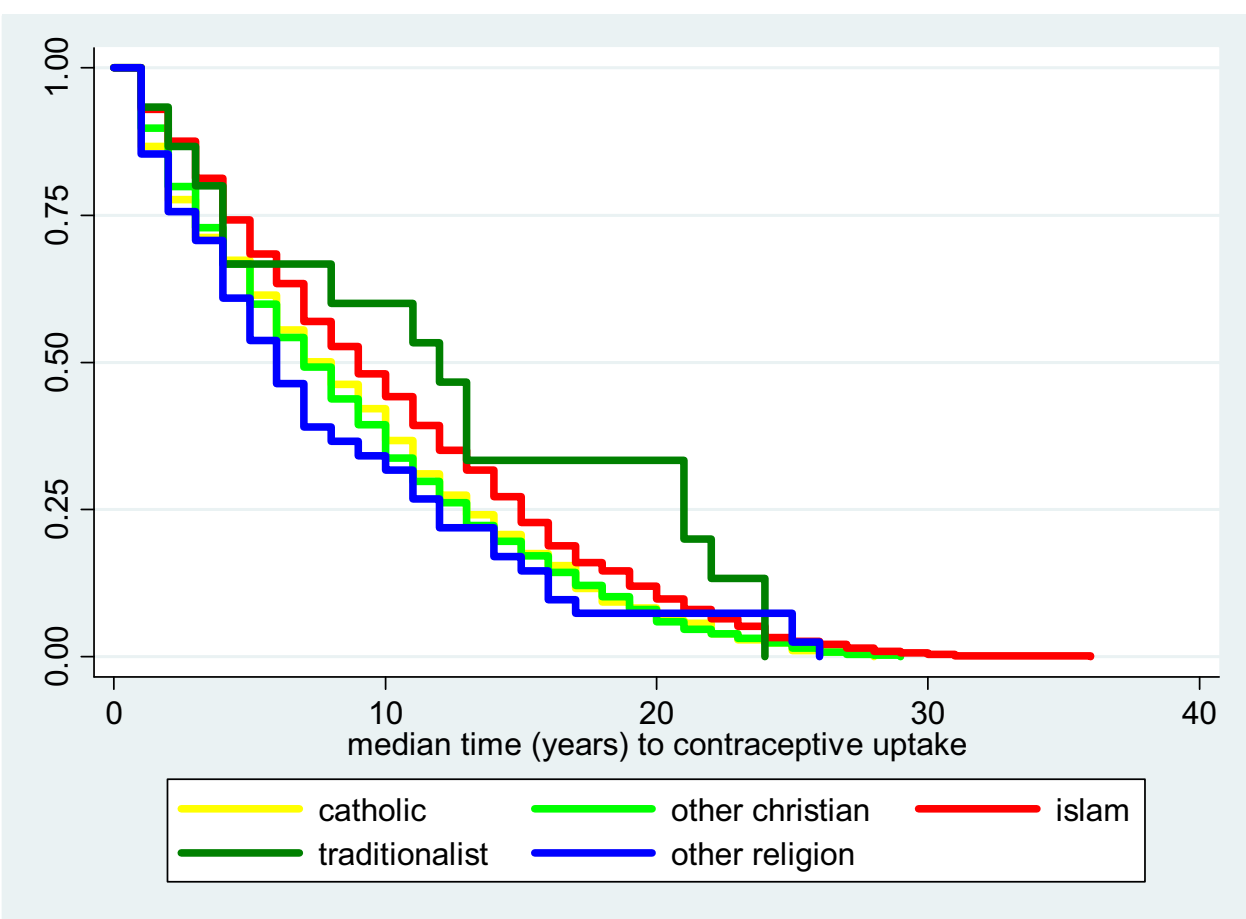

Figure I 3 Median years to FP initiation by religion.

The prevalence of modern contraceptive use reported in this study, which is lower than the prevalence reported for the sub Saharan region, resonates with the national studies reported. ${ }^{4,10,24}$ Similar to other studies, marriage, higher household income, dwelling in an urban area, and media awareness were significant predictors of contraceptive use. Also, higher education, having no unmet need for contraception and being a catholic were predictors of contraceptive use. $^{4,13,15,20,23}$ For instance, rural residents were 26\% less likely to have used contraceptive than urban residents, while those in the highest wealth quintile were $66 \%$ more likely to use contraceptives than those in the lowest quintile. In a similar manner, those who had given birth had a significantly higher chance of using contraceptives than those who had never given birth. This agrees with earlier results which showed that the prevalence of contraceptive use was higher among woman who had given birth compared to those who had not. Women with unmet contraceptive need had 55\% less chance of using contraceptives than women with no unmet contraceptive need.

\section{Strengths and Limitations}

The major strength of our study is the use of a nationally representative sample to assess when Nigerian women initiate contraceptive use and the associated factors. The large sample size will provide plausible comparison. However, this study relied on the recall of participants to determine the time of first sexual activity and modern contraceptive uptake.

\section{Conclusion}

There was low prevalence of contraceptive use among women of reproductive age in Nigeria. There was prolonged time before contraceptive use uptake. There is a need to re-iterate the benefits of contraception and provide enlightenment programs especially in Northern Nigeria and the South east, among rural dwellers and low income earners. The need for constant reminders of the burden of unwanted pregnancies and the dangers of unsafe abortions cannot be over-emphasized. Women who are married were observed to reduce the use of contraceptives. Married women need to be reminded of the importance and benefits of having children by choice rather than by chance (Family 
Table 3 Factors Associated with Contraceptive Utilization Among Women of Reproductive Age

\begin{tabular}{|c|c|c|c|}
\hline Variable & $\begin{array}{l}\text { Adjusted } \\
\text { OR }\end{array}$ & $95 \% \mathrm{Cl}$ & $\mathbf{P}$ \\
\hline \multicolumn{4}{|l|}{ Geopolitical zone } \\
\hline North Central & 1.00 & & \\
\hline North East & 0.80 & $0.64-0.99$ & $0.044^{*}$ \\
\hline North West & 0.82 & $0.7 I-0.94$ & $0.006 *$ \\
\hline South East & 0.53 & $0.44-0.65$ & $<0.001 *$ \\
\hline South South & 0.92 & $0.76-1.11$ & 0.373 \\
\hline South West & 0.98 & $0.82-1.18$ & 0.862 \\
\hline \multicolumn{4}{|l|}{ Place of residence } \\
\hline Urban & 1.00 & & \\
\hline Rural & 0.74 & $0.65-0.84$ & $<0.001 *$ \\
\hline \multicolumn{4}{|l|}{ Wealth index } \\
\hline Lowest & 1.00 & & \\
\hline Lower & 1.40 & $1.21-1.62$ & $<0.001 *$ \\
\hline Middle & 1.38 & $1.15-1.67$ & $0.00 I^{*}$ \\
\hline Higher & 1.59 & $1.29-1.95$ & $<0.001 *$ \\
\hline Highest & 1.66 & $1.33-2.07$ & $<0.001 *$ \\
\hline \multicolumn{4}{|l|}{$\begin{array}{l}\text { Heard about family planning on } \\
\text { radio }\end{array}$} \\
\hline Yes & 1.08 & $0.96-1.20$ & 0.200 \\
\hline No & 1.00 & & \\
\hline \multicolumn{4}{|l|}{$\begin{array}{l}\text { Heard about family planning on } \\
\text { television }\end{array}$} \\
\hline Yes & 1.34 & $|| 9-.|.5|$ & $<0.001 *$ \\
\hline No & 1.00 & & \\
\hline \multicolumn{4}{|l|}{$\begin{array}{l}\text { Read about family planning in } \\
\text { newspaper/magazine }\end{array}$} \\
\hline Yes & 1.06 & $0.93-1.20$ & 0.392 \\
\hline No & 1.00 & & \\
\hline \multicolumn{4}{|l|}{ Ever given birth } \\
\hline Yes & 3.73 & $3.08-4.51$ & $<0.001 *$ \\
\hline No & 1.00 & & \\
\hline \multicolumn{4}{|l|}{ Marital status } \\
\hline Never married & 1.00 & & \\
\hline Married & 0.76 & $0.63-0.93$ & $0.007^{*}$ \\
\hline \multicolumn{4}{|l|}{ Highest level of school attended } \\
\hline No formal education & 1.00 & & \\
\hline Primary & 1.72 & $1.47-2.02$ & $<0.00 I^{*}$ \\
\hline Secondary & 1.99 & $1.68-2.36$ & $<0.001 *$ \\
\hline Higher & 2.09 & $1.70-2.57$ & $<0.001 *$ \\
\hline \multicolumn{4}{|l|}{ Age (years) of respondent } \\
\hline $15-19$ & 1.00 & & \\
\hline 20.24 & 3.34 & $2.72-4.11$ & $<0.001 *$ \\
\hline $25-29$ & 4.84 & $3.89-6.02$ & $<0.001 *$ \\
\hline $30-34$ & 5.10 & $4.06-6.40$ & $<0.001 *$ \\
\hline
\end{tabular}

(Continued)
Table 3 (Continued).

\begin{tabular}{|l|l|l|l|}
\hline Variable & $\begin{array}{l}\text { Adjusted } \\
\text { OR }\end{array}$ & $\mathbf{9 5 \% ~ C I ~}$ & $\mathbf{P}$ \\
\hline $35-39$ & 5.47 & $4.31-6.93$ & $<0.00 I^{*}$ \\
$40-44$ & 4.98 & $3.87-6.4 \mathrm{I}$ & $<0.00$ I $^{*}$ \\
$45-49$ & 3.53 & $2.70-4.6 \mathrm{I}$ & $<0.00 \mathrm{I}^{*}$ \\
\hline Religion & & & \\
Catholic & 1.00 & & \\
Other Christian & 1.02 & $0.87-1.18$ & 0.829 \\
Islam & 0.48 & $0.4 I-0.57$ & $<0.00 I^{*}$ \\
Traditionalist & 0.75 & $0.45-1.23$ & 0.259 \\
Other religion & 1.43 & $0.93-2.20$ & 0.099 \\
\hline Total unmet need & & & \\
No unmet need & 1.00 & & \\
Unmet need & 0.45 & $0.40-0.5 \mathrm{I}$ & $<0.00 I^{*}$ \\
\hline
\end{tabular}

Note: *Significant at $p<0.05$.

Abbreviations: $\mathrm{OR}$, odds ratio; $\mathrm{Cl}$, confidence interval.

Planning), and the socio-economic impact it would have on their families, communities, and country.

\section{List of Abbreviations}

FP, Family Planning; SDGs, Sustainable Development Goals; MMR, Maternal Mortality Ratio; FP2020, Family Planning 2020; NDHS, National Demographic and Health Survey; PMA2020, Performance Monitoring and Accountability 2020; CRERD, Centre for Research, Evaluation Resources and Development; BUK, Bayero University Kano; JHSPH, Johns Hopkins Bloomberg School of Public Health; CIs, Confidence Intervals; OR, Odds Ratio.

\section{Data Sharing Statement}

The PMA2020 dataset used in this study is publicly available at https://www.pma2020.org/data.

\section{Ethics and Consent}

Ethics approval for this study was not required since the data are secondary and available in the public domain. More details regarding PMA2020 data and ethical standards are available at http://PMA2020 Datasets info@pma2020.org.

\section{Consent for Publication}

Not applicable.

\section{Acknowledgments}

We appreciate Centre for Research, Evaluation Resources and Development (CRERD), Bayero University Kano 
(BUK), and the Johns Hopkins Bloomberg School of Public Health (JHSPH) for granting approval to use the data.

\section{Author Contributions}

All authors made a significant contribution to the work reported, whether that is in the conception, study design, execution, acquisition of data, analysis and interpretation, or in all these areas; took part in drafting, revising or critically reviewing the article; gave final approval of the version to be published; have agreed on the journal to which the article has been submitted; and agree to be accountable for all aspects of the work.

\section{Funding}

This research received no grant from any funding agency in the public, commercial or not-for-profit sectors.

\section{Disclosure}

The authors declare that the research was conducted in the absence of any commercial or financial relationships that could be construed as a potential conflict of interest.

\section{References}

1. Girum T, Wasie A. Correlates of maternal mortality in developing countries: an ecological study in 82 countries. Matern Health Neonatol Perinatol. 2017;3(1):19.

2. Schafer MR, Kohn LM. An optimized method for mycelial compatibility testing in Sclerotinia sclerotiorum. Mycologia. 2006;98(4):593-597.

3. Das B, Saha S, Sinha AK, De RC, Nandi AK. Maternal mortality. J Indian Med Assoc. 1990;88(9):249-250.

4. Okunade K, Daramola E, Ajepe A, Sekumade A. A 3-year review of the pattern of contraceptive use among women attending the family planning clinic of a University Teaching Hospital in Lagos, Nigeria. Afr J Med Health Sci. 2016;15(2):69.

5. Cahill N, Sonneveldt E, Stover J, et al. Modern contraceptive use, unmet need, and demand satisfied among women of reproductive age who are married or in a union in the focus countries of the Family Planning 2020 initiative: a systematic analysis using the Family Planning Estimation Tool. The Lancet. 2018;391(10123):870-882.

6. Alkema L, Chou D, Hogan D, et al. Global, regional, and national levels and trends in maternal mortality between 1990 and 2015, with scenario-based projections to 2030: a systematic analysis by the un Maternal Mortality Estimation Inter-Agency Group. The Lancet. 2016;387(10017):462-474.

7. Ahmed S, Li Q, Liu L, Tsui AO. Maternal deaths averted by contraceptive use: an analysis of 172 countries. The Lancet. 2012;380 (9837):111-125.

8. Austin A. Unmet contraceptive need among married Nigerian women: an examination of trends and drivers. Contraception. 2015;91(1):31-38.

9. Rabiu A, Habib R. Feto-maternal outcome of induced versus spontaneous labour in a Nigerian Tertiary Maternity Unit. Trop J Obstet Gynaecol. 2017;34(1):21-27.

10. Osaro B, Tobin-West C, Mezie-Okoye M. Knowledge of modern contraceptives and their use among rural women of childbearing age in Rivers State Nigeria. Ann Trop Med Public Health. 2017;10 (4): 1043.
11. Akwara PA, Noubary B, Lim Ah Ken P, et al. Who is the vulnerable child? Using survey data to identify children at risk in the era of HIV and AIDS. AIDS Care. 2010;22(9):1066-1085.

12. Johnson OE. Determinants of modern contraceptive uptake among Nigerian women: evidence from the national demographic and health survey. Afr J Reprod Health. 2017;21(3):89-95.

13. Babalola S, Oyenubi O. Factors explaining the North-South differentials in contraceptive use in Nigeria: a nonlinear decomposition analysis. Demogr Res. 2018;38(1):287-308.

14. Kalipeni E, Iwelunmor J, Grigsby-Toussaint D. Maternal and child health in Africa for sustainable development goals beyond 2015 . Glob Public Health. 2017;12(6):643-647.

15. Monjok E. Contraceptive practices in Nigeria: literature review and recommendation for future policy decisions. Open Access J Contracept. 2010;(January 2016):9.

16. Ayodeji KO, Erinfolami TP, Oo S, Adebayo SO, Omoluabi EO. Factors Influencing Utilization of Contraceptive Uptake Among Women in Union in Kaduna and Lagos, Nigeria. 2014.

17. Shelton JD. Leading with LARCs in Nigeria: the stars are aligned to expand effective family planning services decisively. Glob Health Sci Pract. 2016;4(2):179-185.

18. Jurczynska K Evidence and advocacy: unlocking resources for family planning in Nigeria. TT-. 2017.

19. Babalola S, Kusemiju B, Calhoun L, Corroon M, Ajao B. Factors associated with contraceptive ideation among urban men in Nigeria. Int J Gynecol Obstet. 2015;130:E42-6.

20. Solanke BL. Factors influencing contraceptive use and non-use among women of advanced reproductive age in Nigeria. $J$ Health Popul Nutr. 2017;36(1):1-14.

21. Adebowale S, Fagbamigbe F, Okareh T, Lawal G. Survival analysis of timing of first marriage among women of reproductive age in Nigeria: regional differences. Afr J Reprod Health. 2012;16 (4):95-107.

22. Ogbuagu CN, Okoli UJ, Ogbuagu CN, Okoli UJ, Oguoma VM, Ogbuagu EN. Orphans and vulnerable children affected by sexual violence and HIV/AIDS in two local government areas in Anambra State Southeastern Nigeria. Am-Eurasian J Sci Res. 2010;5(1):5-11.

23. Kana M, Tagurum Y, Hassan Z, et al. Prevalence and determinants of contraceptive use in rural Northeastern Nigeria: results of a mixed qualitative and quantitative assessment. Ann Niger Med. 2016;10 (1):3.

24. Igbodekwe FC, Oladimeji O, Oladimeji KE, Adeoye IA, Akpa OM, Lawson L. Utilisation of modern contraceptive among women of childbearing age in resource constraint setting: evidence from 2008 National Demographic and Health Survey in Nigeria. J Health Sci. 2014;4(3):72-78.

25. Blackstone SR, Iwelunmor J. Determinants of contraceptive use among Nigerian couples: evidence from the 2013 Demographic and Health Survey. Contracept Reprod Med. 2017;2(1):9.

26. Imo KC, Okoronkwo E, Ukoji V. Interaction effect of knowledge and use of contraceptive methods on fertility among Umuahia women of South-Eastern. J Cult Soc Dev. 2015;5:18-26.

27. Centre for Research, Evaluation Resources and Development (CRERD), Bayero University Kano (BUK), and the Johns Hopkins Bloomberg School of Public Health (JHSPH). Centre for Research, Evaluation Resources and Development (CRERD), Bayero University Kano (BU and the JHBS of PH (JHSPH). Performance Monitoring and Accountability 2020 (PMA2020) Survey Round 4, PMA2017/ Nigeria-R4 (National). Nigeria and Baltimore, Maryland, USA;2017:2017

28. Choi Y, Li Q, Zachary B. Measuring fertility through mobile-phone based household surveys: methods, data quality, and lessons learned from PMA2020 surveys. Demogr Res. 2018;38(55):1663-1698.

29. Jacobstein R. Liftoff: the blossoming of contraceptive implant use in Africa. Glob Health Sci Pract. 2018;6(1):17-39. 
30. Zimmerman L, Olson H, Tsui A, Radloff S. PMA2020: rapid turn-around survey data to monitor family planning service and practice in ten countries. Stud Fam Plann. 2017;48(3):293-303.

31. Tsui AO, Brown W, Li Q. Contraceptive practice in sub-saharan africa: contraceptive practice in sub-Saharan Africa. Popul Dev Rev. 2017;43:166-191. doi:10.1111/padr.12051

32. Rana S Collinearity diagnostics of binary logistic regression model. $2015 ; 2013$.
33. Ekholuenetale M, Ekholuenetale CE, Barrow A. Prognostic factors of time to first abortion after sexual debut among fragile state Congolese women: a survival analysis. BMC Public Health. 2021;21(1):525.

34. Fagbamigbe AF, Adebowale AS, Morhason-Bello I. Survival analysis of time to uptake of modern contraceptives among sexually active women of reproductive age in Nigeria. BMJ Open. 2015;5(12):1-11.

Open Access Journal of Contraception

Dovepress

\section{Publish your work in this journal}

Open Access Journal of Contraception is an international, peerreviewed, open access, online journal, publishing original research, reports, reviews and commentaries on all areas of contraception. In addition to clinical research, demographics and health-related aspects, the journal welcomes new findings in animal and preclinical studies relating to understanding the biological mechanisms and practical development of new contraceptive agents. The manuscript management system is completely online and includes a very quick and fair peer-review system. Visit http://www.dovepress.com/testimonials. php to read real quotes from published authors. 